\title{
SURVEYING THE INFLUENCE OF THE KINESITHERAPEUTIC COMPLEX ON THE SOCIAL AND MENTAL STATUS OF STUDENTS WITH VISUAL DISTURBANCES
}

\author{
Albert Evald ${ }^{1}$, MarianaAlbert $^{2,}$ Evgenia Dimitrova $^{1}$ \\ ${ }^{1}$ National Sports Academy- Sofia, Bulgara \\ ${ }^{2} \mathrm{MU}-$ Sofia, Bulgaria
}

\begin{abstract}
Summary: Young people with visual disturbances during the first semester encounter serious difficulties in adapting to the new life style and the unfamiliar environment. This is a prerequisite for worsening their psycho-emotional state. The researches of a number of authors have suggested that complex rehabilitation leads to the restoration of the social and psychological status of the person.

The study was conducted with students from the "Vision - impaired Massagers" specialty, students from the 1st to 3rd year at "J. Filaretova "Medical College.

The sensor profile was studied by the Dunn test questionnaire (1997).

The analysis of the results has shown that systematic training with specially selected exercises for coordination, equilibrium, qigong and yoga contribute to improving the equilibrium resistance and concentration in students with visual impairment Apparent growth and mental maturity have been observed in both groups.
\end{abstract}

Key words: psycho-emotional state, kinesitherapy, students with visual disturbances

\section{Introduction}

The newly enrolled students with visual impairment face a number of difficulties during the first days of their studies. The unfamiliar environment, the new routes they have to use in the city in order to get from point $\mathrm{A}$ to point $\mathrm{B}$ or from the dormitories to the Campus put their psychic endurance through the mill and provoke complicated experiences and negative reactions.

In order to learn the education material in the various subjects one has to be concentrated and alert. It has been determined that the balance between the processes of arousal and detainment is impaired by the visual disturbances and the memorizing speed is reduced (Radulov, 2010). This leads to difficulties in mastering different motor habits and quick forgetting of the learnt material due to the bad quality of the stored visual images. As a result of these difficulties, the subjects often experience insecurity, strong irritability leading to aggression or passivity, apathy and self-isolation. (Dunn, W., \& Bennett, D.2002).

The research of a number of authors (Lyudmilova, Dimitrova, 2010), (Marinov, 2013) (Radulov 2010), (Deniskina, 2014) shows that in case of visually disabled people the implementation of a complex rehabilitation leads to recovery in the psychic status. The person who practices sports cultivates a renewed adjustment of their auditory perceptions and vestibularis. They control their posture through development of sense of touch, muscle and joint sensibility which compensate for the loss of visual afferent and efferent (Radulov 2010), (Zakirov, Naborshtikova, 2009). Sports activities create a premise for faster adaptation and overcoming social isolation of visually impaired people (Marinov, 2013). It increases the abilities of approval in the society of the people with normal vision (Deniskina, 2014). The regular activities improve their overall health condition; help them at their homes and at their working place (Marinov, 2013).

The implementation of an individual and differentiated approach to the regulation of the physical load should consider the physical fitness and sensory possibilities of the visually impaired.

The aim of the present study is to survey the influence of kinesitherapeutic complex, applied in the sports classes, on the mental status of students with visual disturbances. 
Tasks:

To examine the influence of the complex kinesitherapeutic program on the psychic condition of the students with the use of Dunn questionnaire (1997).

\section{Methodology of the research}

The present study was conducted in the period 2002-2014 with students from the Medical College „Jordanka Filaretova”, Sofia.

The research was done among 105 first- to thirdyear students with visual impairment from both genders, divided into two groups:

I group - experimental group (EG) - 75 students (35 women and 40 men)

II group - control group (CG) - 30 students (15 women and 15 men)

EG consists of students who practice sport regularly in the form of kinesitherapeutic schemes combined with elements from yoga and qigong, modified and enriched by us. All students have presented their medical files and doctor's permission to take part in the experiment.

The average age of the women in both groups is twenty years. The men's mean age is twenty-two years.

All students have a degree of disablement. In the EG $27.9 \%$ of the men and women have first degree of disablement and $71.9 \%$ - second degree. In the CG 26.6\% have the first degree of disablement and $73.3 \%$ - second degree. The distribution of first and second degree of disablement in the groups is even. This calls for an individual approach, differentiated work and consideration of the different degree of visual impairment of each of the subjects.

\section{Organization of the research}

The activities were held twice a week - the regular two sports classes in the curriculum. The duration of the different activities was 45-60 minutes.

The research period was 3 years for each of the students - their entire course of study at the college.

\section{Results and discussion}

These subjects have difficulty in controlling their appearance. The answers to the question, „Is your attire twisted" confirm the positive influence of the academic environment.

The movement of the visually impaired is directly dependable on the degree of disablement and the age it appeared. The deficit of visual afference leads to disturbances in almost all high-handed movements. When asked whether they moved stiffly, the EG answered in the following way during the first testing: $4 \%$ never”, $21.3 \%$ „rarely”, $20 \%$,sometimes”, .25.3\% "often”, and $29.3 \%$ „always”. The results of the CG are the following: $6.7 \%$ „rarely", $26.7 \%$,sometimes”, $.23 .3 \%$ "often”, and $43.3 \%$,always". Both groups together marked $72 \%$ of this serious problem during the first semester. After five semesters of regular activities with specially chosen physical exercises included in the kinesytherapeutic complex, the results of the EG are the following: 10.7\% "never” $32 \%$ „rarely”, $49.3 \%$ „sometimes”, $6.7 \%$ „often”, and 1.3\% "always". The results of the CG are the following: no one marked the answer „never”, $10 \%$ „rarely”, $16.7 \%$ „sometimes", $40 \%$ "often”, and 33.3\% „always". We believe that the achieved results with the EG are due to the various complex of specific exercises for flexibility, stretching, Chinese healing gymnastics qigong, elements from yoga suitable for people with visual impairment which improve their physical qualities.

The coefficient of variation of the EG is $\mathrm{V}=1.52$, and of the CG V=0.99 in the initial testing. During the second testing the coefficient of variation of the EG is $\mathrm{V}=0.68$ and of the $\mathrm{CG} \mathrm{V}=0.93$. Wilcoxon Test shows a statistically significant difference of the indexes of the two surveys of the EG (table 1) and (diagrams 1,2).

When there is a limitation of the visual afference, the sense-motor organization of motor activity is disrupted sharply. The most obvious disturbances are observed in the direction and speed of movement. There is a dominant hyperdynamics in all muscle groups. Most of the visually impaired students find it difficult to move and are characterized with low endurance. The EG answered this question in the preliminary testing in the following way: 9.3\%, never”, $9.3 \%$ „rarely”, $21.3 \%$ „sometimes”, $40 \%$ "often", and $20 \%$,always". The CG did not give "never” and "rarely” answers, but 10\% marked „sometimes”, 30\% “often”, and 60\% „always”. Both groups show low endurance in the initial testing. 
The fact that most of the respondents have low physical endurance and some of them had not attended any physical education classes is alarming.

The results of the CG in the second testing are the following: $23.3 \%$ „sometimes”, $50 \%$ “often”, and $26.7 \%$ „always"; the answers „never” and „rarely” were not marked, which allows us to conclude that the problem with low physical endurance had not been overcome.

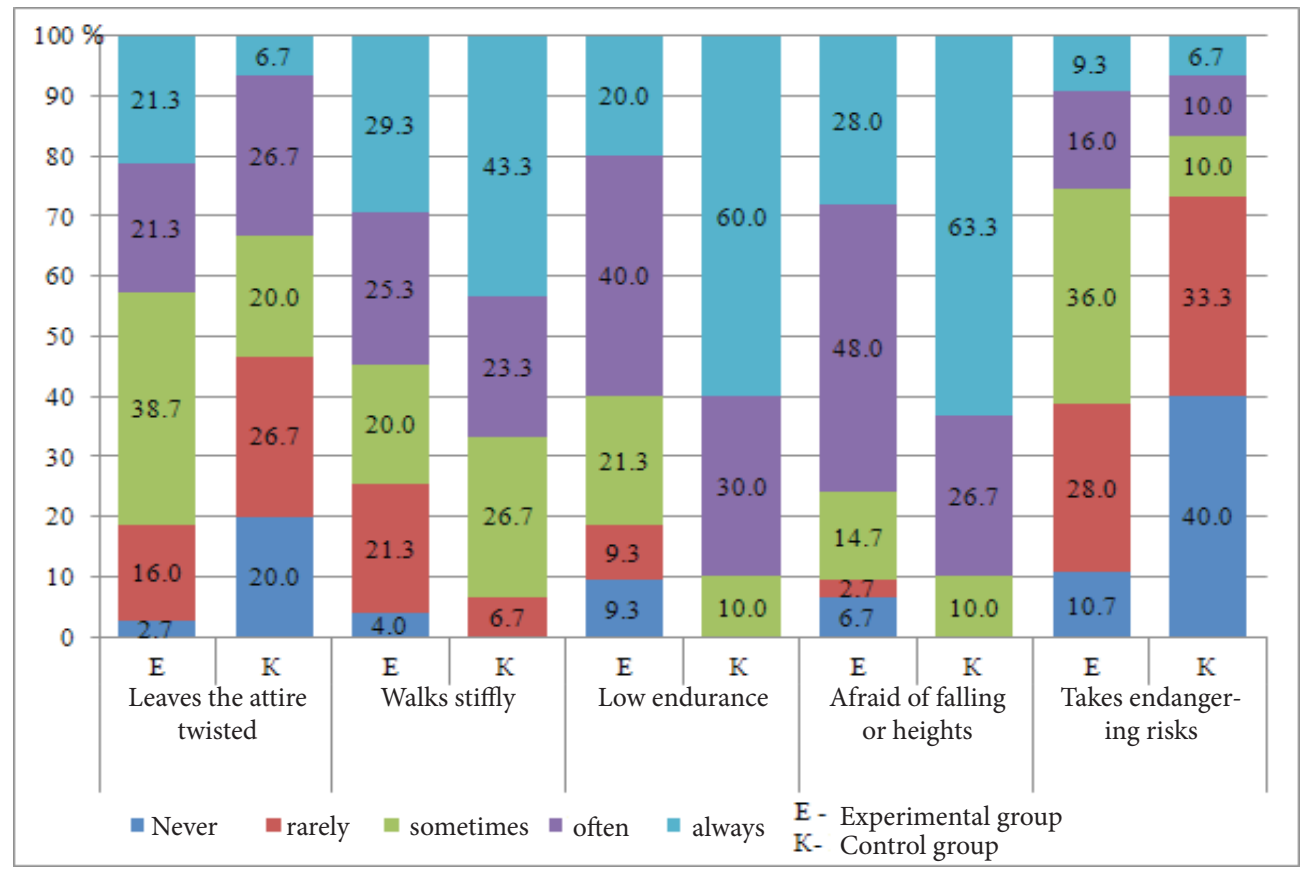

Chart 1. Distribution of the answers of the EG and CG during the first semester in percentage

We applied kinesytherapeutic complex with duration of five semesters with strict observance of its stages. The main physical qualities strength, speed, flexibility, endurance, balance and coordination were developed continuously and consecutively during each stage. In the end, the EG showed the following results: $25.3 \%$ "never”, $29.3 \%$ "rarely”, $28 \%$ „sometimes”, $13.3 \%$ „often”, and $4 \%$ „always”. The coefficient of variation of the EG is $\mathrm{V}=1.42$, and of the CG V $=0.46$ in the initial testing. In the second testing the coefficient of variation of the EG is $\mathrm{V}=1.27$, and of the $\mathrm{CG} \mathrm{V}=0.51$.

Fear of falling of heights is the most common with the visually impaired. In their daily routine, especially in the cities, their most serious problem is getting to the university or to the hospital because of the many obstacles they face such as cars parked on the pavement, rough roads and excavations.
During the first semester the CG answered this question in the following way: "never”, "rarely" were not marked, $10 \%$ „sometimes”, $26.7 \%$ „often”, and $63.3 \%$ „always". The answers of the EG were: $6.7 \%$ „never”, $2.7 \%$ „rarely”, $14.7 \%$ „sometimes”, $48 \%$ „often”, and $28 \%$,always" (chart1).

The percentage of the students in both groups who are always afraid of falling or heights is significant. During the second testing the groups showed the following results: the CG did not mark "never" and „rarely”, 33.3\% „sometimes”, 33.3\% “often”, and $33.3 \%$,always". The results of the EG were the following: 38.7“",rarely”, 14.7\% „sometimes”, 38.7\% „often”, and 4\% „always” (Chart 2). The coefficient of variation of the EG is $V=1.13$, and of the $C G V=$ 0.46 in the initial testing. During the second testing the coefficient of variation of the $\mathrm{EG}$ is $\mathrm{V}=1.34$, and of the CG V $=0.69$ (Tables 1, 2). 
Table 1. Dunn test data of the CG from first and fifth semesters

\begin{tabular}{|l|l|l|l|l|l|l|l|l|l|l|l|}
\hline CG question & N & Range & Min. & Max & Mean & $\begin{array}{l}\text { Std. } \\
\text { Devia- } \\
\text { tion }\end{array}$ & Var & Sk & \multicolumn{2}{l|}{ Kurtosis } \\
\hline Moves stiffly & 30 & 3 & 2 & 5 & 4,03 &, 999 &, 999 &,- 514 &, 427 & $-1,013$ &, 833 \\
\hline Moves stiffly 2 & 30 & 3 & 2 & 5 & 3,97 &, 964 &, 930 &,- 672 &, 427 &,- 362 &, 833 \\
\hline Weak endurance & 30 & 2 & 3 & 5 & 4,50 &, 682 &, 466 & $-1,047$ &, 427 &,- 034 &, 833 \\
\hline Weak endurance 2 & 30 & 2 & 3 & 5 & 4,03 &, 718 &, 516 &,- 050 &, 427 &,- 954 &, 833 \\
\hline $\begin{array}{l}\text { Afraid of falling } \\
\text { or heights }\end{array}$ & 30 & 2 & 3 & 5 & 4,53 &, 681 &, 464 & $-1,179$ &, 427 &, 229 &, 833 \\
\hline $\begin{array}{l}\text { Afraid of falling } \\
\text { or heights 2 }\end{array}$ & 30 & 2 & 3 & 5 & 4,00 &, 830 &, 690 &, 000 &, 427 & $-1,554$ &, 833 \\
\hline $\begin{array}{l}\text { Takes endanger- } \\
\text { ing risks }\end{array}$ & 30 & 4 & 1 & 5 & 2,10 & 1,242 & 1,541 & 1,073 &, 427 &, 235 &, 833 \\
\hline $\begin{array}{l}\text { Takes endanger- } \\
\text { ing risks 2 }\end{array}$ & 30 & 4 & 1 & 5 & 1,83 & 1,020 & 1,040 & 1,610 &, 427 & 2,651 &, 833 \\
\hline
\end{tabular}

Table 2. Dunn test data of the EG from first and fifth semesters

\begin{tabular}{|l|l|l|l|l|l|l|l|l|l|l|l|}
\hline EG question & N & Range & Min. & Max & Mean & $\begin{array}{l}\text { Std. } \\
\text { Dev. }\end{array}$ & \multicolumn{2}{l|}{ Var } & \multicolumn{2}{l|}{ Sk } & \multicolumn{3}{l|}{ Kurtosis } \\
\hline Moves stiffly & 75 & 4 & 1 & 5 & 3,55 & 1,23 & 1,52 &,- 31 &, 28 & $-1,11$ &, 55 \\
\hline Moves stiffly 2 & 75 & 4 & 1 & 5 & 2,56 &, 83 &, 68 &,- 05 &, 28 &, 28 &, 55 \\
\hline Weak endurance & 75 & 4 & 1 & 5 & 3,52 & 1,19 & 1,42 &,- 72 &, 28 &,- 24 &, 55 \\
\hline Weak endurance 2 & 75 & 4 & 1 & 5 & 2,41 & 1,13 & 1,27 &, 40 &, 28 &,- 62 &, 55 \\
\hline $\begin{array}{l}\text { Afraid of falling } \\
\text { or heights }\end{array}$ & 75 & 4 & 1 & 5 & 3,88 & 1,06 & 1,13 & $-1,2$ &, 28 & 1,53 &, 55 \\
\hline $\begin{array}{l}\text { Afraid of falling } \\
\text { or heights 2 }\end{array}$ & 75 & 4 & 1 & 5 & 2,92 & 1,16 & 1,34 &,- 16 &, 28 & $-1,23$ &, 55 \\
\hline $\begin{array}{l}\text { Takes endanger- } \\
\text { ing risks }\end{array}$ & 75 & 4 & 1 & 5 & 2,85 & 1,11 & 1,23 &, 24 &, 28 &,- 48 &, 55 \\
\hline $\begin{array}{l}\text { Takes endanger- } \\
\text { ing risks 2 }\end{array}$ & 75 & 3 & 1 & 4 & 2,05 & 1,05 & 1,11 &, 54 &, 28 &,- 98 &, 55 \\
\hline
\end{tabular}

As a result of the adaptation processes and regular participation in the sports classes there are also some changes in the results of the CG. It is indicative there were no answers "never" and "rarely", which showed that the main problem had not been solved. To some extent, there was a partial overcoming of this problem with $63.3 \%$ of the students who marked the answer "always" in the second testing, and $33.3 \%$ of them marked the answers "always", „often”, and „sometimes”. The EG group marked all answers unlike the CG.

Due to the balance and coordination exercises, as well as the special exercises taken from qigong and yoga, the students had developed better orientation and sense of the spatial position of their body; their reactions had improved and this helped them to overcome the obstacles on the road easily. Last but not least, during their studies, their mobility had increased significantly. The results from the statistical analysis with the test of Mann-Whitney and T-criterion of Wilcoxon justify this fact (table 1).

The last question in Dunn test concerns the occasional infantile behaviors of the visually impaired who take risky actions. Sometimes they tend to show their desire they are complete people and can cope in difficult and dangerous situations. The results of the two groups during the first semester were: EG - 10.7\% „never”, $28 \%$, „rarely”, 36\% „sometimes", $16 \%$ often”, and 9.3\% „always". CG $40 \%$ „never”, 33.3 „rarely”, 10\% „sometimes”, 10\% "often", and $6.7 \%$ „always”. 


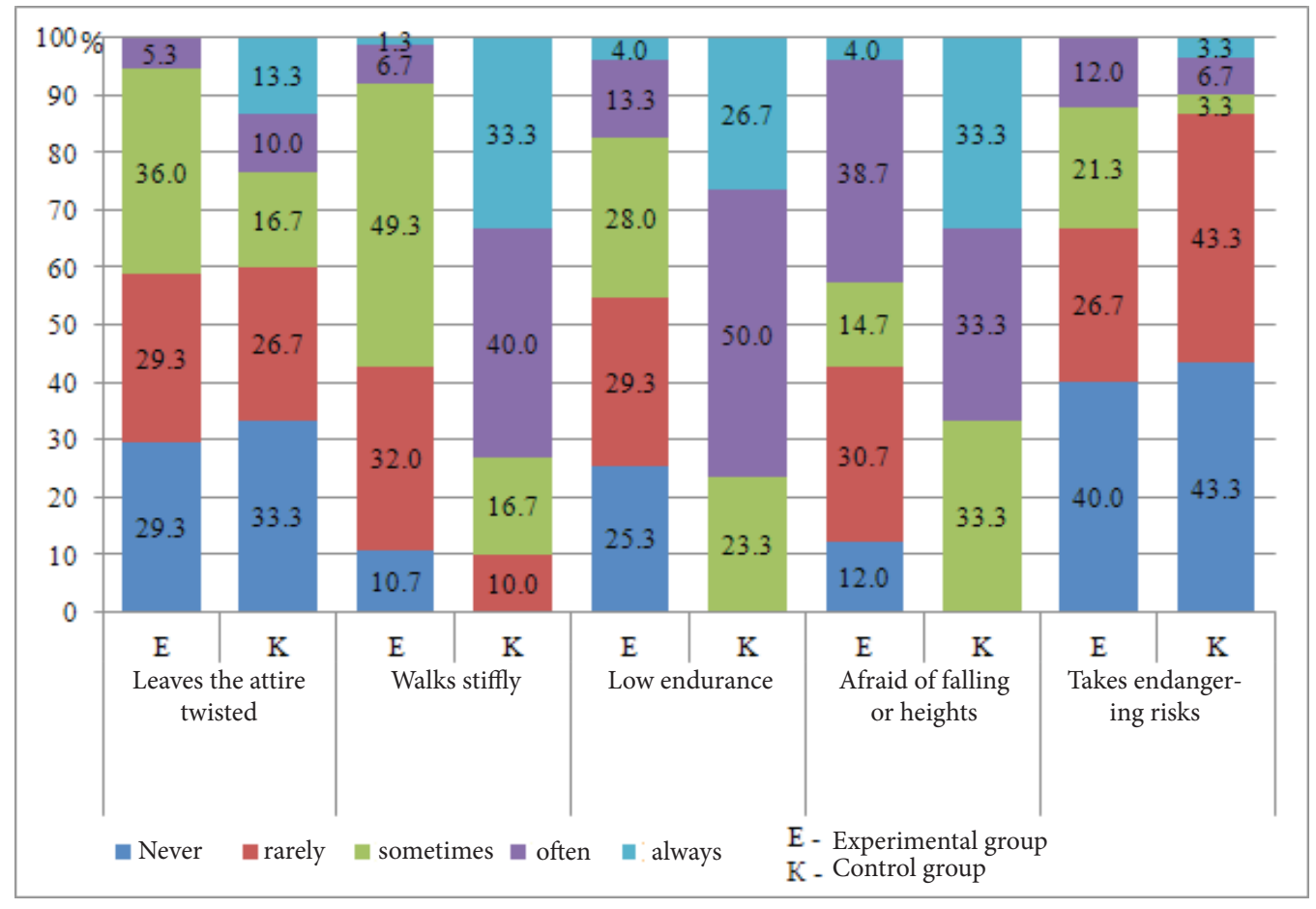

Chart 2. Distribution of the answers of the EG and CG during the fifth semester in percentage

At the end of the fifth semester the CG showed the following results: $43.3 \%$ "never", 43.3 "rarely”, $3.3 \%$ „sometimes”, $6.7 \%$ „often”, and $3.3 \%$,always”, and the EG marked the following: $40 \%$ never", 26.7 "rarely”, $21.3 \%$ „sometimes”, $12 \%$ „often”; no one marked the answer "always". The coefficient of variation of the EG is $\mathrm{V}=1.23$, and of the $\mathrm{CG} V=1.54$ in the initial testing. In the second testing the coefficient of variation of the EG is $\mathrm{V}=1.11$, and of the CG V = 1.40 (table 2). We have to point out there is visible growth and psychic maturity of the two groups. In the CG there is a small percentage of people who are willing to risk "always" in extreme situations, unlike the students in the EG.

The increase in the percentage of the students who reject extreme behavior is significant - from $10.7 \%$ to $40 \%$, with the EG, while with the CG the change is from $40 \%$ to $43.3 \%$. The positive results, in our opinion, are due to the beneficial influence of the exercises taken from the eastern practices which balance the nervous system and urge the players to harmony and balance.

The comparative analysis of the results with the T-criterion of Wilcoxon shows that the indexes characterizing the physical endurance in the final testing are with high guarantee probability $(\mathrm{P} \geq$
95\%). So, we can reject the zero hypotheses and accept the alternative one. According to it, the results of the EG, after the implementation of the kinesytherapeutic complex, are significantly higher than the ones of the CG along the researched index and are indicative of its efficiency. The values of T-criterion, presented in tables 1 and 2 and charts 1 and 2 , justify this.

\section{Conclusion}

The proposed kinesytherapeutic complex has positive influence on the psychic-emotional condition of the visually impaired students and helps them to overcome the difficulties. Thanks to the regular physical activities, the percentage of the students showing psychic maturity and social adaptation has increased. The students have developed better spatial orientation, their reactions have improved and this helps them to avoid the obstacles on the road to a certain extent. Last but not least, their mobility has increased significantly during the period of their studies.

\section{References:}

Lyudmilova, I., Dimitrova, D., 2010, Vliyanie na sportnata aktivnost varhu silovata izdrajlivost na deca s uvredeno zrenie. Sports, stress, adaptaciya. 1, Peti Internationalen Nautchen Congress Olimpiiski Sport i Sport za 
Vsichki, Sofia p. 398. // Людмилова, И., Димитрова, Д. Влияние на спортната дейност върху силовата издръжливост на деца и младежи с увредено зрение. // Спорт, стрес, адаптация. ч. 1, Пети международен научен конгрес Олимпийски спорт и спорт за всички., С., 2010, с. 398.

Marinov, E. Rehabilitacia I ergoterapia pri deca sas specialni obrazovatelni potrebnosti. Sofia, UI "Sv. K. Ohridski”, 2013, s. 135 // Маринов, Е. Рехабилитация и ерготерапия при деца със специални образователни потребности. С., УИ „Св. К. Охридски”, 2013, с. 135

Radulov, V. Manieristichno povedenie pri zritelno zatrudneni. Obuchenie I rehabilitacia na zritelno zatrudnenite. 2010, tom XXIII, p. 10-26 // Радулов, В. Маниеристично поведение при зрително затруднени. Обучение и рехабилитация на зрително затруднените., 2010, том XXIII, с. 10-26.

Deniskina, V., 2012 Educational Needs, Substantial Disorders and Secondary Impacts. Defectology, 5, pp. 56-64. // Денискина, В. Особые образовательные потребности, обусловленные нарушениями зрения и их вторичными последствиями. // Дефектология. 2012, 5, c. 56-64.

Zakirov, R. Naborshtikova, Y. Korekcionnaia napravlenosti procesa obuchenia tehniko-takticheskim podgotvitelnim destiam unih dziudoistov s narusheniem zrenia. Fizicheskaia kultura: vospitanie, obrazovanie, trenirovka. Moskva, 2009, 6, p.70 // Закиров, Р., Наборщикова, Ю. Корекционная направленость процесса обучения технико-тактическим подготвительным действиям юных дзюдоистов с нарушением зрения. Физическая культура: воспитание, образование, тренировка, М., 2009, 6, c. 70.

Dunn, W., \& Bennett, D. Patterns of sensory processing in children with attention deficit hyperactivity disorder. Occupational Therapy Journal of Research, 2002, 22, p. 4-15.

Dunn, W. The impact of sensory processing abilities on the daily lives of young children and families: A conceptual model. Infants and Young Children, 1997, 9, 23-25. 